\title{
CHANGES IN THE USE OF IT TECHNOLOGIES BY STUDENTS OF AGRICULTURAL FACULTIES
}

\begin{tabular}{|c|c|}
\hline \multicolumn{2}{|c|}{ Edmund Lorencowicz ${ }^{\mathrm{a}}$, Milan Koszel ${ }^{\mathrm{a}}$, Sławomir Kocira ${ }^{\mathrm{a}}$, Jacek Uziak ${ }^{\mathrm{b}}$} \\
\hline \multicolumn{2}{|c|}{ *Corresponding author: edmund.lorencowicz@up.lublin.pl } \\
\hline ARTICLE INFO & ABSTRACT \\
\hline $\begin{array}{l}\text { Article history: } \\
\text { Received: August } 2016 \\
\text { Received in the revised form: } \\
\text { September } 2016 \\
\text { Accepted: November } 2016 \\
\end{array}$ & $\begin{array}{l}\text { Research on the selected population of students with a standardized } \\
\text { questionnaire method concerning the use of IT technologies has been } \\
\text { carried out since } 2008 / 09 \text {. Results for the data from the first and the } \\
\text { last year of research ( } 2009 \text { and 2016) for agricultural students were } \\
\text { compared. It was reported that students use IT technologies in the }\end{array}$ \\
\hline $\begin{array}{l}\text { Key words: } \\
\text { computer use, } \\
\text { internet use, } \\
\text { computer program use, } \\
\text { students, internet }\end{array}$ & $\begin{array}{l}\text { process of learning. Majority of students }-94 \% \text { (2009) and } 98 \% \\
\text { (2016) positively assessed the usefulness of these technologies in the } \\
\text { learning process. The Internet was used mainly for communication } \\
\text { (respectively in the investigated years } 82.5 \% \text { and } 99.1 \% \text { ). Usefulness } \\
\text { of the Internet in the process of studying was marked very high - in } \\
2009 \text { it was } 51 \% \text { positive answers and in } 2016-77 \% \text {. }\end{array}$ \\
\hline
\end{tabular}

\section{Introduction}

According to the data of the Main Statistical Office (Berezowska et al., 2014, 2015) the informatization level of the Polish society has changed considerably. For example, participation of households equipped with computers raised from $59 \%$ to $78 \%$ (table 1 ). Almost $65 \%$ of the investigated persons used a computer on a regular basis in 2015 , which constitutes an increase by 14.9 of the percentage point in comparison to 2008. Participation of households which have access to the Internet raised by 28.4 of the percentage point and in case of eastern Poland this value was 32.8 of the percentage point. As much as $97 \%$ of young people aged 16-24 uses a computer on a regular basis and almost $85 \%$ connects to the Internet through mobile devices (Table 1).

This type of changes is reflected also in the population of young people who study at agricultural faculties at the Polish academic institutions. Fast progress in the development of IT causes that next classes of students who start an educational cycle at universities use new programs and devices.

Therefore, the objective of the research was to determine changes in the IT use by the investigated individuals in academic years 2008/09 and 2015/16 at agricultural faculties of the Department of Production Engineering of the University of Life Sciences in Lublin. 
Edmund Lorencowicz, Milan Koszel, Sławomir Kocira, Jacek Uziak

Table 1.

Comparison of statistical data concerning development of computer techniques in Poland in 2008 and 2015

\begin{tabular}{|c|c|c|c|}
\hline Specification & Value for 2009 & Value 2016 & $\begin{array}{c}\text { Change } \\
\text { 2015-2009 }\end{array}$ \\
\hline Computers in households (at least one) & $58.9 \%$ & $77.9 \%$ & $+19.0 \%$ \\
\hline $\begin{array}{l}\text { Individuals who use a computer on a regular } \\
\text { basis including: }\end{array}$ & $49.9 \%$ & $64.8 \%$ & $+14.9 \%$ \\
\hline - aged 16-24 & $89.9 \%$ & $97.0 \%$ & $+7.1 \%$ \\
\hline - pupils and students & $96.2 \%$ & $99.1 \%$ & $+2.9 \%$ \\
\hline Access to the Internet & $47.6 \%$ & $75.8 \%$ & $+28.4 \%$ \\
\hline Broadband Internet access & $37.9 \%$ & $71.0 \%$ & $+32.1 \%$ \\
\hline Frequency of the Internet usage - regularly & $44.3 \%$ & $64.8 \%$ & $+20.5 \%$ \\
\hline $\begin{array}{l}\text { Individuals using the Internet with reference } \\
\text { to the place of use - home }\end{array}$ & $40.4 \%$ & $66.3 \%$ & $+25.9 \%$ \\
\hline - workplace & $14.7 \%$ & $22.7 \%$ & $+8.0 \%$ \\
\hline $\begin{array}{l}\text { Purpose of the Internet use: } \\
\text { - e-mail }\end{array}$ & $77.5 \%$ & $79.4 \%$ & $+1.9 \%$ \\
\hline $\begin{array}{l}\text { - searching for information on goods and } \\
\text { services }\end{array}$ & $66.5 \%$ & $62.1 \%$ & $-5.4 \%$ \\
\hline - reading, downloading journals on-line & $38.3 \%$ & $68.6 \%$ & $+30.3 \%$ \\
\hline - using bank services & $35.0 \%$ & $45.9 \%$ & $+10.9 \%$ \\
\hline - making calls, on-line video-conferences & $35.2 \%$ & $40.6 \%$ & $+5.4 \%$ \\
\hline - using tourist-related web sites & $28.6 \%$ & $25.2 \%$ & $-3.4 \%$ \\
\hline - downloading computer programs & $25.4 \%$ & $16.4 \%$ & $-9.0 \%$ \\
\hline - searching for work, sending offers & $16.6 \%$ & $14.5 \%$ & $-2.1 \%$ \\
\hline - selling goods on auctions & $13.7 \%$ & $17.8 \%$ & $-4.1 \%$ \\
\hline $\begin{array}{l}\text { - connecting to the Internet through mobile } \\
\text { devices }\end{array}$ & $21.9 \%(2012)$ & $43.9 \%$ & $+22,0$ \\
\hline - aged 16-24 years & $46,3 \%(2012)$ & $84.5 \%$ & $+38.2 \%$ \\
\hline
\end{tabular}

\section{Materials and methods}

Empirical material was collected during surveys carried out in 2009 and 2016 among the selected group of students. The questionnaire was divided into parts which covered, inter alia, such issues as:

- respondent's characteristics (including: faculty and year as well as a place of residence),

- owned computer equipment, used programs and internet access,

- manners an frequency of using a computer,

- manners and frequency of using the internet,

- assessment of IT usefulness in studying.

A measurement based on Likert's scale was used for evaluation of computers and the Internet use (Jezior, 2013). It allowed a further analysis with the use of a semantic differential, bdw). 
Changes in the use...

The research covered 320 (2009) and 340 (2016) students. From among the investigated respondents in 2009, 62.8\% came from rural areas and in 2016 they constituted 58.5\%. During studies in 2009, majority of them lived in a family home (65.6\%), 19.1\% in lodgings and $13.4 \%$ in a dormitory. In 2016 a greater part of the investigated students lived in lodgings (51.2\%), 37.6\% in a family home and $9.1 \%$ in a dormitory.

Data collected in 2016 were compared to those obtained in 2009 (Lorencowicz and Kocira, 2009).

\section{Research results}

In the investigated period, changes occurred in the type of usage of computer equipment. In 2009 it mainly was a stationary equipment (49.4\%) and in 2016 it was only 17.9\%. Development of IT and digitalization facilitated the access to mobile devices. Declaration as to owning a mobile computer in 2009 was made by $39.7 \%$ of students and in 2016 the number of students reached as much as 92.1\%. In $200979.4 \%$ of students declared that they owned a computer and in $2016-94.7 \%$.

Table 2 presents the most often owned programs in 2009 and 2016.

Table 2.

Programs used by the questioned students in the process of studying (\%)

\begin{tabular}{lccc}
\hline \multirow{2}{*}{ Specification of a programme } & \multicolumn{2}{c}{ Percentage of respondents } & Change \\
\cline { 2 - 4 } & 2009 & 2016 & $2016-2009$ \\
\hline MS Office & 84.39 & 91.47 & +7.1 \\
Other spreadsheets & 5.63 & 5.00 & -0.63 \\
Other editors & 4.69 & 3.53 & -1.16 \\
Graphic programs & 3.13 & 15.59 & +12.46 \\
CAD, SOLID type of programs & 6.56 & 10.00 & +3.44 \\
Writing programs & 5.00 & 2.06 & -2.94 \\
Other specialist programs & 5.94 & 2.65 & -3.29 \\
\hline
\end{tabular}

MS Office is the most often used computer program. In 2009 over $80 \%$ of respondents declared that they had this program and in 2016 - over $90 \%$. Also programs such as CAD, SOLID (respectively in $2009-6.6 \%$ and in $2016-10.00 \%$ ) and in 2016 graphic programs (15.6\%) were popular.

Frequency of the use of computers was varied. Over $74 \%$ of students surveyed in 2009 used a computer at least once a week. In 2016 the interest of students using computers at least once a week dropped to 58\%. Almost 25\% (2009) of students used computers rarely than once a week. In 2016 this interest increased to over 40\%. This increase may result from using smart phones and tablets.

Students eagerly used computers for listening to music and watching films (2009 $53.5 \%$ of the surveyed and $2016-63.1 \%$ of surveyed). Simultaneously, the highest number of students declared that they play games rarely than once a week $-30.2 \%$ (2009) and $41.3 \%$ (2016).

Students in a decisive majority assess positively usefulness of a computer for studying. Over 94\% (2009) claims that a computer is very useful or useful for studying. Only $4 \%$ of 
the surveyed people claim that a computer is useful sometimes and only two respondents $(0.6 \%)$ believe that a computer is useless. There was no answer that a computer is useful only for entertainment. On the other hand, among the questioned students in 2016, 98\% claimed that a computer is very useful or useful for studying. Only $0.5 \%$ claims that a computer is useful in the process of studying sometimes and only one respondent $(0.3 \%)$ believed that a computer is useless for this purpose.

Analysis of the differential of changes of the frequency of using computers allows an observation that there was an increase in the frequency in each investigated use (Fig. 1). The lowest increase occurred in "Games" and the highest in "Making technical drawings".

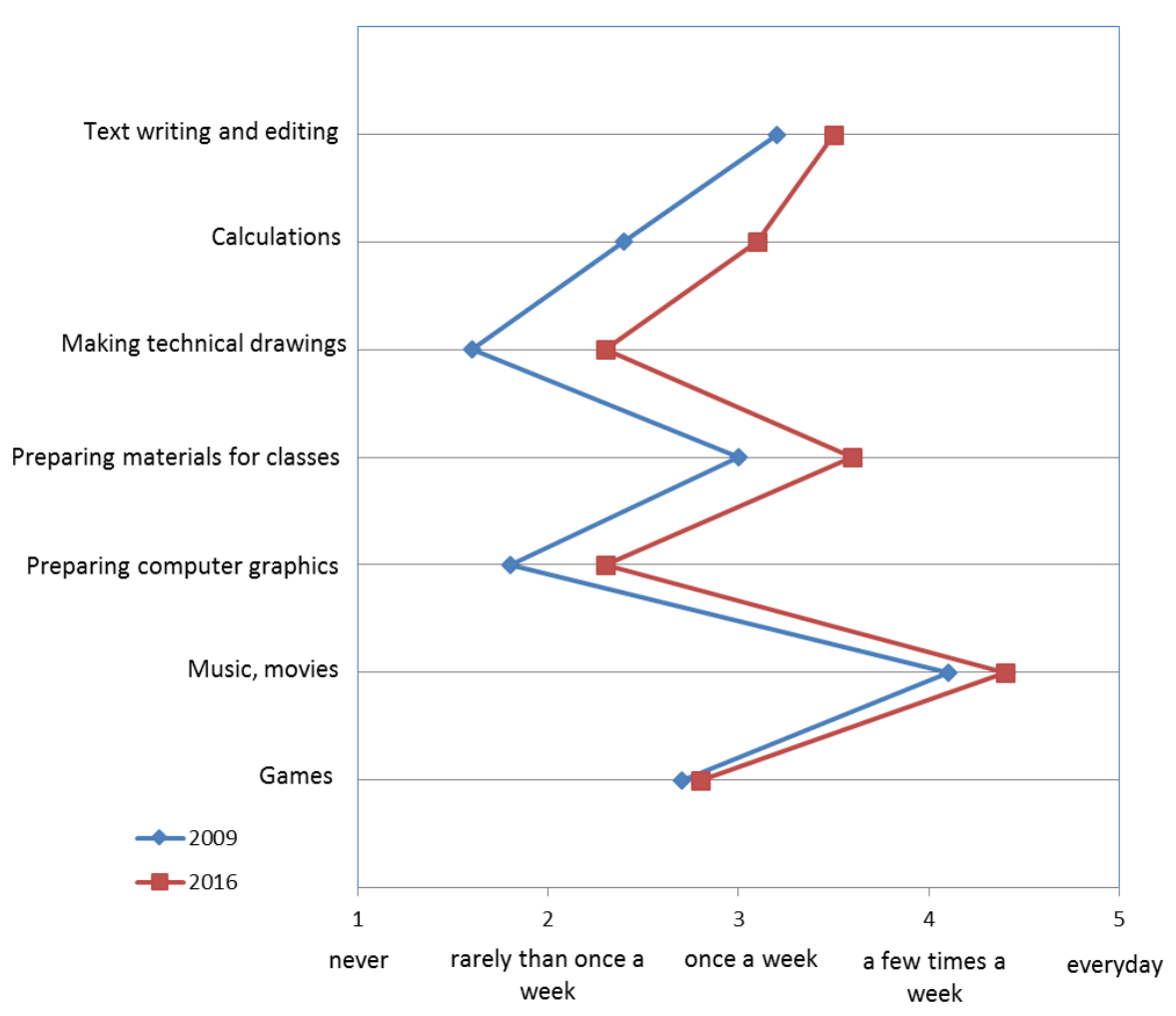

Figure 1. Differential of changes of computer use frequency

Changes also occurred in the access to the Internet. The number of students who have access to the Internet in the place of living increased by $10 \%(2009-88.1 \%, 2016-$ 98.2\%). Also the access to the Internet in other places increased $(2009-3.7 \%, 2016-$ $15.0 \%)$, in the internet cafe or through a hot-spot (2.8\% and $9.4 \%)$ and at the friend's house $(9.7 \%$ and $11.2 \%)$. In $2016-78.8 \%$ of respondents declared the use of a mobile internet. 
Changes in the use...

In 2009 the most frequent use of the Internet was for communication by e-mails - 294 (82.5\%) and as much as 74\% did it every day or several times a week. In 2016, the number of students using e-mails increased to $99.1 \%$ and $73 \%$ of them did it every day or several times a week.

Such communicators as "gadu-gadu" and "skype" were popular among students because as much as $48.7 \%$ - 2009 and $51.8 \%$ - 2016 used them every day. This form of conversation was preferred in total by $79.4 \%-2009$ and $33498.2 \%-2016$ of students.

Students used the Internet as a source of obtaining data. $90 \%$ of all people taking part in the questionnaire in 2009 and $90.3 \%$ in 2016 searched for practical information and news in the Internet. 25\% students in 2009 did it every day and 33.2\% in 2016. The Internet is also a source of information related to attended classes during the process of studying. It is proved by the number of students who search there for information needed for classes $88.7 \%$ in 2009 . In 2016 - the number of students who searched for information related to the attended classes in the process of studying decreased by $17.6 \%$ and it was $71.2 \%$. The process of searching was carried out every day or several times a day by respectively $60.9 \%$ and $55.9 \%$ of students. In 2009 75.3\% of respondents searched the Internet for information related to organization of studies. In 2016 the increase of the number of respondents who searched for information related to organization of studies took place to $95.9 \%$.

From among 320 surveyed students (2009), 237 (74.1\%) searched the Internet for music, films and photographs. $27.8 \%$ searched for music, films, photographs-related information everyday or a few times a week. Almost $65 \%$ of student surfed the net - including 116 who did it every day and 50 a few times a week. On the other hand, in 2016 the number of students searching the Internet for music, movies or photos increased (338-99.4\%). 151 students (44.4\%) did it every day and 120 people (35.3\%) a few days a week. The number of questioned who "surf" the net - 336 persons (98.8\%). 257 of them did it every day and 60 a few days a week.

Respectively $199(62.2 \%$ - 2009) and 334 (98.1\% - 2016) declared that they use the Internet for practical reasons e.g. shopping. The shopping was not made on a regular basis which is proved by a high number of students who buy only from time to time - rarely than once a week (119 and 207).

Games are one of the entertainment forms in the Internet. Less than half of the respondents in 2009 (47.5\%) namely 152 persons played various types of games in the Internet. 33 students played every day, 41- a few times a week, 23 - once a week and 55 - from time to time. From among the surveyed persons in 2016 a decisive majority of them played such games $(328-96.5 \%) .41$ students played every day, 41 a few times a week, 36 - once a week and 207 - from time to time. 


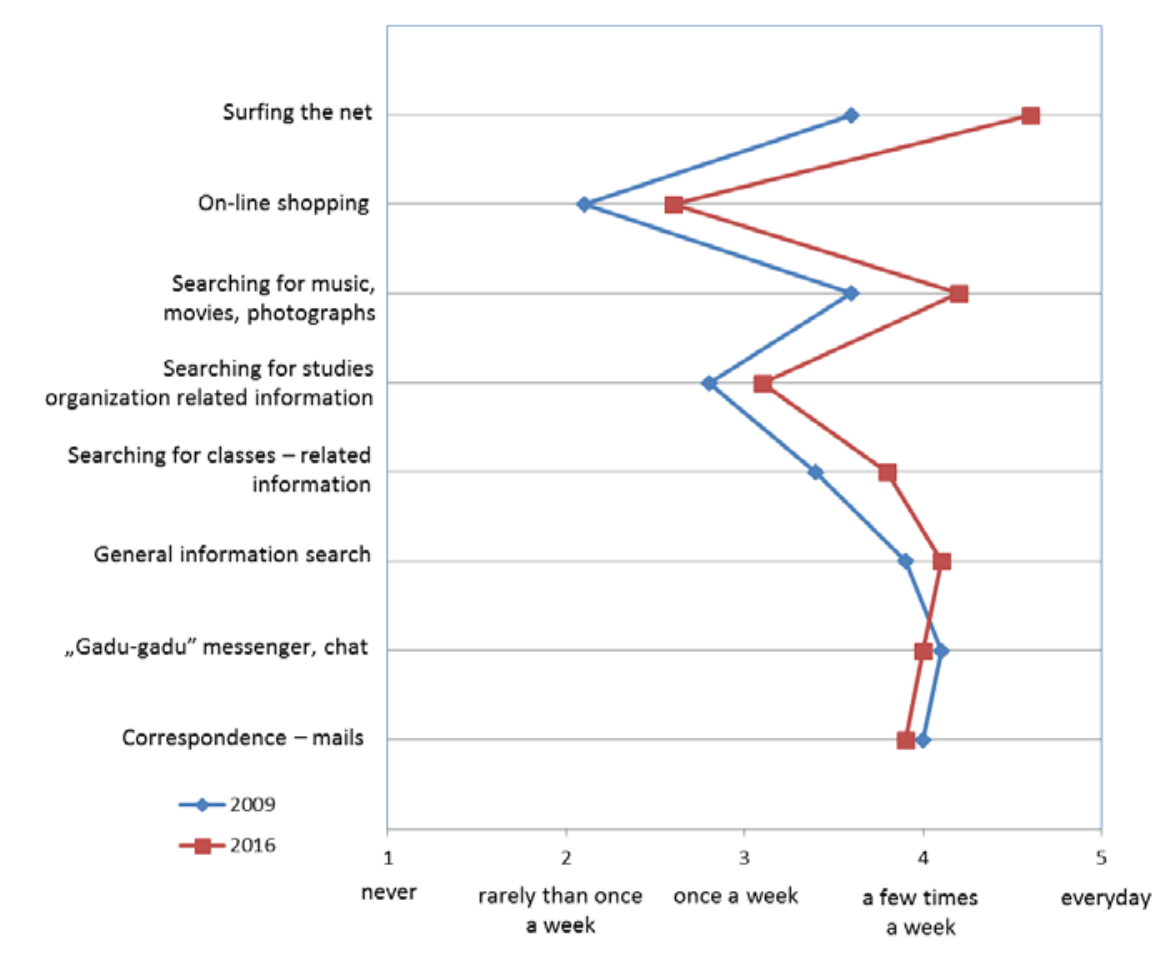

Figure 2. Differential of changes of frequency in the Internet use

It may be assumed that the frequency increased in case of five forms of the Internet use (Fig. 2). Decrease took place in case of the use of communicators and e-mails. The initial analysis shows that it results from the increase of popularity of social media, which ensure the possibility of communication, without the necessity of starting additional applications.

The surveyed students assessed usefulness of resources and possibilities which the Internet provides during the course of studies. As much as 164 (51.3\%) in 2009 assessed the Internet as a very useful tool and $39(12.2 \%)$ as useful. In 2016 - 262 people $(77.1 \%)$ assessed the Internet as a very useful in the process of studying and 20 students (5.9\%) as useful. Nobody from among the questioned evaluated the Internet as a useless tool and nobody recognized it as useful in terms of entertainment. Such opinion is confirmed by foreign researchers (Annan-Coultas, 2012; Mac Callum and Jeffrey, 2013).

\section{Conclusion}

The investigations that were carried out proved a common use of computers and the Internet resources among students. Comparison of the obtained results shows a $15 \%$ increase in the number of respondents who have their own computer. Over $90 \%$ of students questioned in 2016 declared that they have a mobile computer while in 2009 this participation 
Changes in the use...

was $40 \%$. Analysis of the obtained results proves the increase in the number of computer programs users. MS Office is the most often used program related to the studies. The surveyed also declared the use of graphic programs and programs of CAD, SOLID type.

Students used the Internet most often in the place of living, which proves common access to the Internet. The highest number of students used the Internet for communication, mainly by e-mails and chats. A big interest of the surveyed students searched the Internet for information related to attended classes and arrangement of studies. Students do not prefer systematic shopping via the Internet. It is proved by the low number of purchases made in a week - namely less than once a week.

According to students a computer and the Internet is very useful in the course of studies.

The collected data and their analysis enables a statement that students are very closely related to the IT. Almost everyone has their own stationary or a mobile computer device. They claim that computers and the IT are useful in the process of learning. These opinions are reflected in the foreign research (Abilene Christian University 2011; Ally, 2009) and the Polish ones (Feiner 2012; Koszel et al., 2015; Lorencowicz et al., 2009 i 2013). According to Roberts and Rees (2014) mobile devices are presently widely used by students which may cause problems related to, inter alia, their use in classes for the purposes not related to education.

\section{References}

Abilene Christian University. (2011). 2010-11 Mobile learning report. http://www.acu.edu /technology/mobilelearning/documents/ACU_M-_2010-11.pdf, 20.04.2014

Ally, M. (Ed). (2009). Mobile learning: transforming the delivery of education and training. $A U$ Press, Athabasca University, Edmonton, Canada.

Annan-Coultas, D. (2012). Laptops as instructional tools: Student perceptions. TechTrends, 56(5), 34-41.

Berezowska, J., Huet, M., Kamińska, M., Kwiatkowska, M., Orczykowska, M., Rozkrut, D., Wegner, M. (2015). Społeczeństwo informacyjne w Polsce. Wyniki badań z lat 2011-2015. Informacje i Opracowania Statystyczne, Warszawa, 193.

Berezowska, J., Huet, M., Kamińska, M., Kwiatkowska ,M., Rozkrut, D., Szczepańska, B. (2012). Społeczeństwo informacyjne w Polsce. Wyniki badań z lat 2008-2012. Informacje i Opracowania Statystyczne, Warszawa, 143

Dyferencjał semantyczny. https://mfiles.pl/pl/index.php/Dyferencja\%C5\%82_semantyczny

Feiner, J. (2012). Metodyczne aspekty wykorzystania technologii informacyjnej w procesie kształcenia studentów AGH. http://winntbg.bg.agh.edu.pl/skrypty/0037/cz4-r39.pdf, 22.03.2015.

Jezior, J. (2013). Metodologiczne problemy zastosowania skali Likerta w badaniach postaw wobec bezrobocia. Przeglą Socjologiczny, 1, 117-138.

Koszel, M., Kocira, S., Lorencowicz, E. (2015). Zmiany w technikach komunikacji internetowej studentów. Edukacja-Technika-Informatyka, 4(14),118-124.

Lorencowicz, E., Bejgrowicz, A., Kocira, S., Lorencowicz, H. (2013). Use of Information Technology by Selected Polish and Portuguese Students. Studies \& Proceedings of the Polish Association for Knowledge Management, 67, 54-69,

Lorencowicz, E., Kocira, S. (2009). Wykorzystanie komputerów i Internetu przez studentów studiów o profilu rolniczym. Inżynieria Rolnicza, 9(118), 121-129.

Lorencowicz, E., Koszel, M., Kocira, S., Uziak J. (2009). Changes in ICT use by polish students from life sciences university. Procedia - Social and Behavioral Sciences, 176(2015), 117-123. DOI:10.1016/j.sbspro.2015.01.451. 
Edmund Lorencowicz, Milan Koszel, Sławomir Kocira, Jacek Uziak

Mac Callum, K., Jeffrey, L. (2013). The influence of students' ICT skills and their adoption of mobile learning. Australasian Journal of Educational Technology, 29(3), 303-314.

Roberts, N., \& Rees, M. (2014). Student use of mobile devices in university lectures. Australasian Journal of Educational Technology, 30 (4), 415-426.

\section{ZMIANY W WYKORZYSTANIU TECHNOLOGII INFORMACYJNYCH PRZEZ STUDENTÓW STUDIÓW O PROFILU ROLNICZYM}

Streszczenie. Badania na wybranej populacji studentów metodą wywiadu standaryzowanego dotyczące wykorzystania technologii informacyjnych prowadzono od roku akademickiego 2008/09. Porównano wyniki dla danych z pierwszego i ostatniego roku badań (2009 i 2016) dla studentów studiujących w obszarach związanych z rolnictwem. Stwierdzono, że studenci wykorzystują technologie informacyjne w procesie studiowania. Większość studentów - 94\% (2009) i 98\% (2016) pozytywnie ocenia przydatność tych technologii w studiowaniu. Internet był wykorzystywany głównie do komunikowania sie (odpowiednio w badanych latach 82,5\% i 99,1\%). Przydatność Internetu w procesie studiów oceniona została bardzo wysoko - w roku 2009 było to $51 \%$ odpowiedzi pozytywnych i w 2016 roku 77\%.

Słowa kluczowe: wykorzystanie komputerów, wykorzystanie internetu, wykorzystanie programów komputerowych, studenci, internet 